\title{
Ca-Fe-RICH PYROXENES IN MIOCENE PERLITES FROM THE TSUGAWA AND TADAMI AREAS, NORTHEAST JAPAN
}

\author{
Mitsuo Shimazu \\ Niigata University, Niigata \\ and \\ MASAKI TAKano \\ Niigata Prefectural Government
}

\begin{abstract}
Phenocrysts of Ca-Fe-rich pyroxenes such as ferroangite and ferrohedenbergite were found in perlite lavas, which occur in the Middle Miocene formations in the Tsugawa and Tadami areas, although many of acid volcanic rocks in the areas consist of phenocrysts of biotite or hornblende. These perlites consist of phenocrysts of plagioclase (andesineoligoclase), ferroaugite or ferrohedenbergite, altered olivine and titanomagnetite in a pale brown glassy groundmass.

Ferroaugite and ferrohedenbergite occur in the British and Icelandic Tertiary acid glass and the late stages of the Skaergaard and Bushveld intrusions. Such pyroxenes also occur in some alkaline rocks. On the $\mathrm{Ca}-\mathrm{Mg}-\mathrm{Fe}$ quadilateral, chemical compositions of Ca-Fe-rich pyroxenes from the perlites are plotted near the trend curve of pyroxenes of tholeiitic rocks and are lower $\mathrm{TiO}_{2}, \mathrm{Al}_{2} \mathrm{O}_{8}$ and $\mathrm{K}_{2} \mathrm{O}$ contents than those from alkaline rocks.
\end{abstract}

\section{INTRODUGTION}

Various pyroxenes in the Tertiary acid glasses were studied by Anwar (1955), Carmichael (1960) and Emeleus et al. (1971). Anwar (1955) described ferrohedenbergites from Meall Dearg granophyre of Skye. Carmichael (1960) also investigated Fe-rich pyroxenes and olivines from British and Icelandic Tertiary porphyritic acid glasses, which form acid dykes, pitchstone margins of acid intrusives and lavas. In Japan, Fe-rich augite, ferropigeonite and olivine from Asio andesite and dacite were described by Kuno (1969).

The authors have found ferrohedenbergite and ferroaugite from Middle Miocene perlites of the Tsugawa and Tadami areas. The modes of occurrence and chemical compositions of these pyroxenes, and their genetic relations, compared with similar pyroxenes from other localities, are discussed in this paper.

Acknowledgement: The authors wish to express their gratitude to Prof. Kenzo Yagi of Hokkaido University for critical reading of the manuscript.

\section{Geological Setting}

The Tsugawa and Tadami areas are situated in the southern part of the Inner belt of Northeast Japan, which belong to the Green Tuff region. The Middle Miocene formation named the Tsugawa Formation in the Tsugawa area is composed of rhyolitic pyroclastics and lavas with conglomerate, sandstone and mudstone. Volcanic rocks of this formation are interpreted as products 


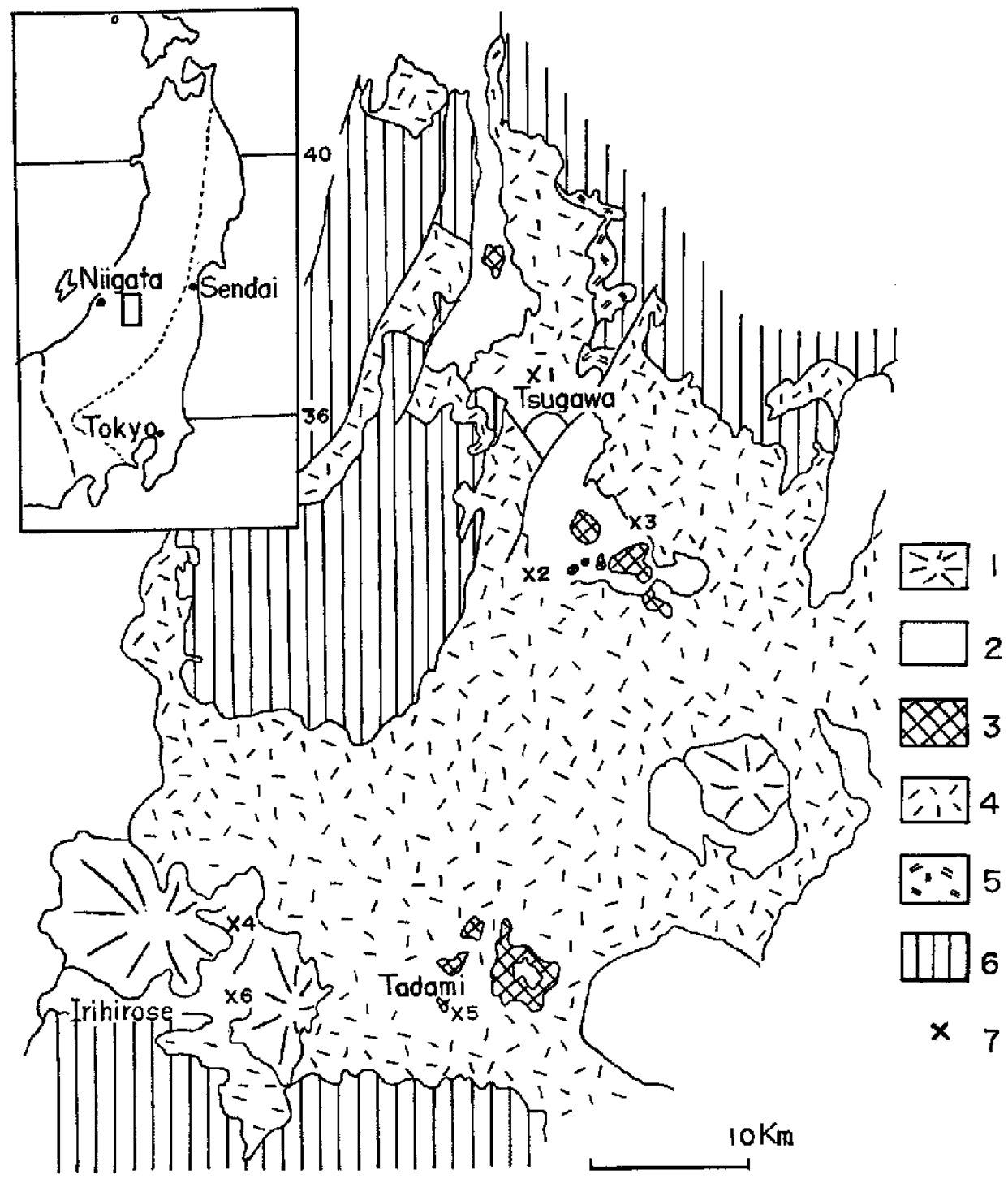

Fig. 1. Geologic map of the Tsugawa and Tadami areas.

1. Quaternary volcanoes, 2. Neogene formation covering the Tsugawa Formation, 3. Basaltic rocks, 4. Tsugawa Formation. 5. Neogene formation underlain by the Tsugawa Formation. 6. Paleozoic and granite. 7. Localities of pyroxene perlites.

of submarine eruption, because of existence of foraminiferal and marine molluskan fossils in intercalated sandstone and mudstone. Perlite lavas, which form the upper member of the Tsugawa Formation, are distributed in the northwestern and southern parts of the Tsugawa area, covered by thick mudstones of the Nanatani Formation. Some perlites include ferroaugite or hornblende or biotite phenocrysts.

In the Tadami area, the formation corresponding to the Tsugawa Formation is divided into the following three formations in the ascending order; the Takizawa Forma- 
tion, Oshio Formation and Ogawazawa Formation. The former two formations are composed of thyolitic lavas and their pyroclastics and mudstones. The Ogawazawa Formation covers unconformably the Oshio Formation and is mainly composed of black- or green-colored perlite lavas, containing ferrohedenbergites. It is intruded by the dyke swarms of basalt of tholeiite composition and rhyodacite, with the northsouth direction.

\section{Petrography}

Ferroaugite perlite, Suwa pass, Tsugawa. This forms a lava flow in the upper part of the Tsugawa Formation. It is dark grey to black in color and consists of phenocrysts of plagioclase $\left(\mathrm{An}_{\mathbf{3 5}-43}\right)$, ferroaugite, titanomagnetite (Usp 48\%) and ilmenite $\left(\mathrm{Fe}_{2} \mathrm{O}_{3}\right)$ $8 \%$ ) in a pale brown glassy groundmass showing perlitic texture. Plagioclase is euhedral and shows zonal structure. Ferroaugite is subhedral and is green in color. Olivine is completely altered to saponite. Glass is partly replaced by celadonite, chalcedny and mordenite. Similar ferroaugite perlites occur in Semigadaira and Myoga in southern part of Tsugawa, and in Gomizawa west of Tadami.

Ferrohedenbergite perlite, Kurosawa, Tadami. This is a lava flow of the Ogawazawa Formation. It shows black color with pearly luster, but partly shows grass green color owing to alteration minerals such as celadonite. It consists of phenocrysts of plagioclase, ferrohedenbergite, olivine and magnetite set in pale brown glassy groundmass showing perltic texture. Plagioclase $\left(\mathrm{An}_{23-26}\right)$ is euhedral and shows zonal structure. Ferrohedenbergite is subhedral to euhedral and shows brownish green color. Olivine is completely altered to saponite.
Augite-hyperstheme perlite, Gomizawa, west of Tadami. This is found as a block in the tuff breccia of the Tsugawa Formation. It is pale green in color and consists of phenoycrsts of plagioclase, augite and hypersthene in dark brown glass. Plagioclase $\left(\mathrm{An}_{38-40}\right)$ is euhedral and has zonal structure. Augite is euhedral and pale greenish in color. Hypersthene is euhedral and pale brown in color. Glass is partly replaced by chalcedny.

Chemical compositions of some perlites are shown in Table 1. With the exception of pyroxene perlites mentioned-above, most of the acidic volcanic rocks of the Tsugawa

Table 1. Chemical compositions of perlite and glass of groundmass of perlites from the Tsugawa and Tadami areas.

\begin{tabular}{lrrr}
\hline & \multicolumn{1}{c}{1} & 2 & \multicolumn{1}{c}{3} \\
\hline $\mathrm{SiO}_{2}$ & 75.20 & 76.8 & 76.4 \\
$\mathrm{TiO}_{2}$ & 0.10 & 0.1 & 0.3 \\
$\mathrm{Al}_{2} \mathrm{O}_{3}$ & 10.40 & 12.5 & 11.9 \\
$\mathrm{Fe}_{2} \mathrm{O}_{3}$ & 1.16 & 1.9 & 2.3 \\
$\mathrm{FeO}$ & 0.22 & & \\
$\mathrm{MnO}$ & 0.33 & & \\
$\mathrm{MgO} \mathrm{O}$ & 0.38 & 0.0 & 0.2 \\
$\mathrm{CaO}$ & 1.02 & 0.9 & 1.4 \\
$\mathrm{Na}_{2} \mathrm{O}$ & 1.38 & 1.8 & 0.1 \\
$\mathrm{~K}_{2} \mathrm{O}$ & 6.16 & 3.9 & 0.6 \\
$\mathrm{H}_{2} \mathrm{O}+$ & 2.55 & & \\
$\mathrm{H}_{2} \mathrm{O}-$ & 1.17 & & \\
$\mathrm{P}_{2} \mathrm{O}_{5}$ & 0.03 & & \\
\hline $\mathrm{Total}_{2}$ & 100.10 & 97.9 & 93.2 \\
\hline
\end{tabular}

1. Ferrouagite perlite, Myoga, Tsugawa (Abe and Shimazu, 1974).

2. Glass of groundmass of ferrohedenbergite perlite, Kurosawa, Tadami.

3. Glass of groundmass of ferroaugite perlite, Suwa pass, Tsugawa.

2 and 3 were analyzed by microprobe and total iron is represented as $\mathrm{Fe}_{2} \mathrm{O}_{3}$. 
Formation and its correspoinding formations are various rhyolite lavas and their pyroclastics. Rhyolite lavas are grey or greyish red in color and are mostly lithoidite. Some of them have phenocrysts of plagio-

Table 2. Chemical compositions of volcanic rocks from the Tsugawa area.

\begin{tabular}{lrrrrr}
\hline $\mathrm{No}$. & \multicolumn{1}{c}{1} & \multicolumn{1}{c}{2} & \multicolumn{1}{c}{3} & \multicolumn{1}{c}{4} & 5 \\
\hline $\mathrm{SiO}_{2}$ & 73.82 & 82.65 & 69.78 & 74.98 & 77.67 \\
$\mathrm{TiO}_{2}$ & 0.13 & 0.13 & 0.11 & 0.15 & 0.13 \\
$\mathrm{AI}_{2} \mathrm{O}_{3}$ & 11.52 & 8.84 & 11.35 & 13.76 & 11.64 \\
$\mathrm{Fe}_{2} \mathrm{O}_{3}$ & 0.63 & 1.45 & 0.88 & 1.26 & 1.08 \\
$\mathrm{FeO}^{2}$ & 0.25 & 0.17 & 0.32 & 0.35 & 0.20 \\
$\mathrm{MnO}$ & 0.03 & 0.02 & 0.05 & 0.02 & 0.02 \\
$\mathrm{MgO}$ & 0.12 & 0.10 & 0.93 & 0.28 & 0.19 \\
$\mathrm{CaO}$ & 0.94 & 1.03 & 1.11 & 0.37 & 0.83 \\
$\mathrm{Na}{ }_{2} \mathrm{O}$ & 3.12 & 3.07 & 2.24 & 4.25 & 3.31 \\
$\mathrm{~K}_{2} \mathrm{O}$ & 3.84 & 1.70 & 2.88 & 3.52 & 4.02 \\
$\mathrm{H}_{2} \mathrm{O}+$ & 5.16 & 0.34 & 6.22 & 0.68 & 0.47 \\
$\mathrm{H}_{2} \mathrm{O}-$ & 0.36 & 0.30 & 3.86 & 0.24 & 0.19 \\
$\mathrm{P}_{2} \mathrm{O}_{5}$ & 0.05 & 0.04 & 0.05 & 0.05 & 0.04 \\
\hline $\mathrm{Tota1}$ & 99.97 & 99.84 & 99.78 & 99.91 & 99.79 \\
\hline $\mathrm{Q}$ & 38.92 & 56.04 & 39.29 & 35.73 & 40.59 \\
$\mathrm{Or}$ & 22.69 & 10.05 & 17.02 & 20.80 & 23.75 \\
$\mathrm{Ab}$ & 26.40 & 25.98 & 18.96 & 35.96 & 28.01 \\
$\mathrm{An}$ & 4.34 & 4.85 & 5.16 & 1.49 & 5.02 \\
$\mathrm{C}$ & 0.64 & 0.17 & & 2.41 & \\
$\mathrm{WO}$ & & & 5.49 & & \\
$\mathrm{En}$ & 0.30 & 0.25 & 2.32 & 0.70 & 0.47 \\
$\mathrm{Mt}$ & 0.53 & 0.24 & 0.71 & 0.71 & 0.26 \\
$\mathrm{Hm}$ & 0.27 & 1.29 & 0.39 & 0.77 & 0.82 \\
$\mathrm{Am}$ & 0.25 & 0.25 & 0.21 & 0.28 & 0.25 \\
$\mathrm{Ap}$ & 0.12 & 0.09 & 0.12 & 0.12 & 0.09 \\
\hline
\end{tabular}

1. Hormblende-biotite perlite, Myoga, Tsugawa (Abe and Shimazu, 1974).

2. Rhyodacite (lava), Hirotani, Tsugawa (Ditto. No. 9).

3. Rhyodacite (dyke), Kamikawa, Tsugawa (Mean values of compositions of three samples, No. 1,2 and 3 in Table 2).

4. Rhyodacite (dyke), Kamikawa, Tsugawa (Mean values of compositions of three samples, No. 6 , 7 and 10 in Table 2).

5. Rhyodacite (dyke), Tsugawa (Mean values of compositions of three samples, No. 8,11 and 12 in Table 2). clase and/or quartz and others have biotite and/or hornblende phenocrysts with plagioclase and/or quartz, or they are completely aphyric. Rhyolite dykes intruding these formations also have the same characters. Most of the groundmass of rhyolite are altered and replaced by sericite, quartz and zeolite.

Chemical compositions of rhyolites are shown in Table 2 (Abe and Shimazu, 1974). $\mathrm{SiO}_{2}$ contents have range of 69.78 75.20 percent, $\mathrm{Na}_{2} \mathrm{O}$ contents range of 1.38 4.25 and $\mathrm{K}_{2} \mathrm{O}$ contents range of 1.70-6.16. Ferroaugite perlite have high $\mathrm{K}_{2} \mathrm{O}$ content, when compared with ordinary rhyolites (Table 1, No. 1). The normative Q-Or-AbAn diagram indicates that most of the rocks are classified into thyodacite to dacite and ferroaugite perlite into rhyolite by Streckeisen's classification.

\section{MINERALOGY}

\section{Analytical technique}

Chemical analyses were made with a JXA-5A electron probe microanalyzer associated with a PDP 8/f mini-computer in our laboratory. Analyses were reduced on-line with the program of JEOL written by JECASS language employing the correction scheme of Bence and Albee. Quantitative analyses were made at $15 \mathrm{kv}$ and below $0.03 \mu \mathrm{A}$ of specimen current with an $\mathrm{X}$-ray spot size in the range $2-3 \mu$. Synthetic diopside, natural kaerusutite and rhodonite were used as standard materials.

\section{Clinopyroxene}

Crystals of ferrohedenbergite occurring as phenocrysts in the perlites are brownish green in color and elongated parallel to caxis, attaining $0.5 \mathrm{~mm}$ in length. They have not zoning and mosaic texture, which suggest that they were inverted from iron- 

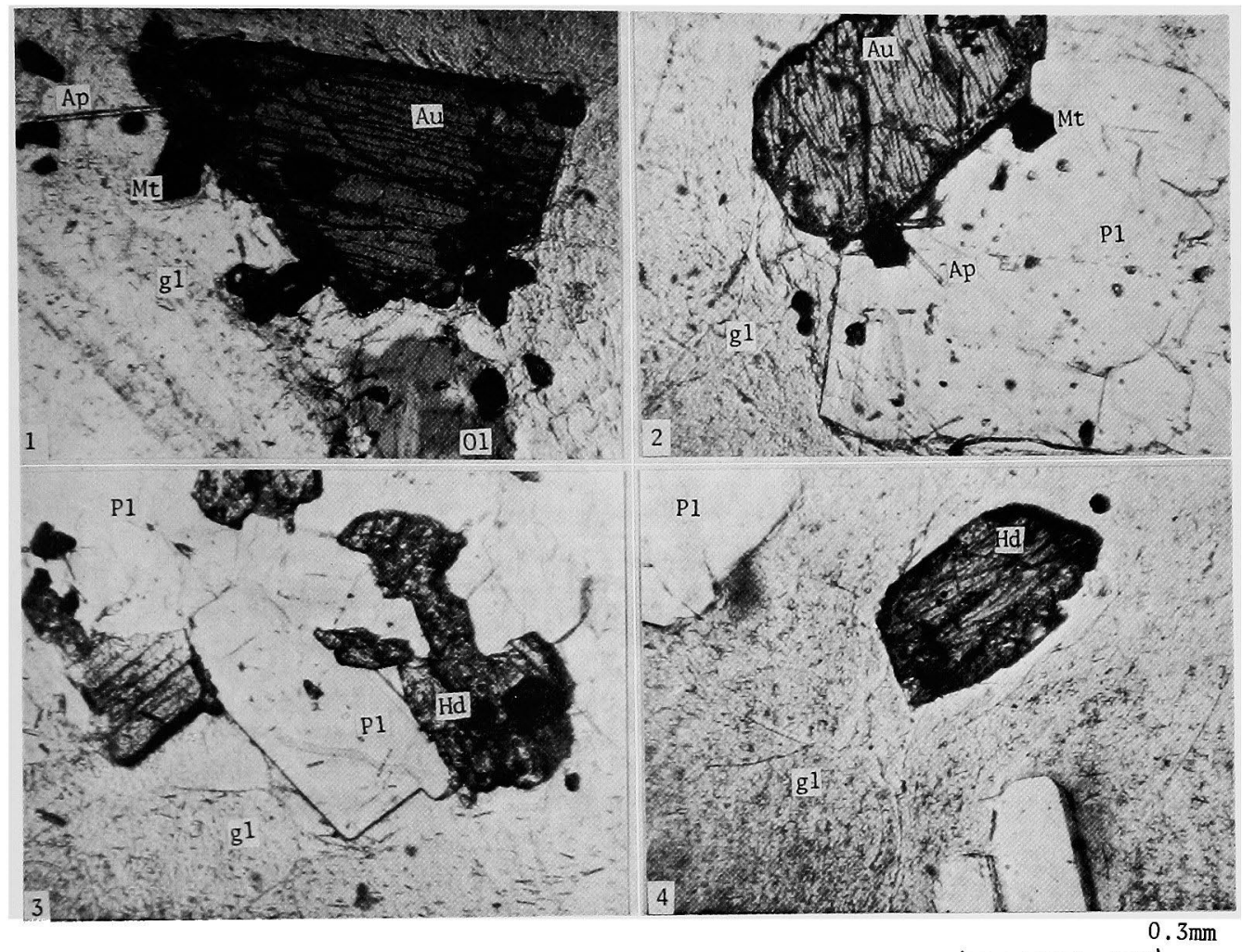

Fig. 2. Photomicrographs of perlites.

1,2 ... Ferroaugite perlite, Suwa pass, Tsugawa.

$3,4 \ldots$ Ferrohedenbergite perlite, Kurosawa, Tadami

$\mathrm{Au}$ : Ferroaugite, $\mathrm{Hd}$ : Ferrohedenbergite, Ol: Saponite after olivine Pl: Plagioclase,

Ap: Apatite, Mt: Titanomagnetite.

wollastonite. Ferrhoendenbergites occur either associated with plagioclase or enclosed in plagioclase. Crystals of ferroaugite are pale green in color attaining $0.3 \mathrm{~mm}$ in length.

Chemical compositions of eight pyroxene crystals from five rocks are presented in Table 3 , together with their structural formula. The variation in composition can be best shown by plotting on $\mathrm{Ca}-\mathrm{Mg}-\mathrm{Fe}$ diagram (Fig. 3). For comparison with pyroxenes from alkaline rocks, they are also plotted on $\mathrm{Na}-\mathrm{Mg}-\mathrm{Fe}$ diagram (Fig. 4).

Comparative chemistry of the pyroxenes

Anwar (1955) and Carmichael (1960) have analzyed many Ca- and Fe-rich clinopyroxenes and some orthopyroxenes from the British and Icelandic Tertiary acid glasses. Ca-poor Fe-rich pyroxenes from British Tertiary acid hypabyssal rocks have been analyzed by Emeleus et al. (1971), and those from the Tertiary Asio andesite and dacite by Kuno (1969).

$\mathrm{Ca}$ - and Fe-rich clinopyroxenes have been reported also by Brown and Vincent (1963) from the late stages of fractionation of the Skaergaard intrusion; by Atkins (1969) from the Bushveld intrusion; by McDougall (1961) from the Red Hill dolerite: by Konda and Green (1974) from the 
Table 3. Microprobe analyses of pyroxenes from the Tsugawa and Tadami areas.

\begin{tabular}{|c|c|c|c|c|c|c|c|c|}
\hline & 1 & 2 & 3 & 4 & 5 & 6 & 7 & 8 \\
\hline $\mathrm{SiO}_{2}$ & 52.41 & 50.95 & 47.53 & 48.14 & 50.77 & 50.30 & 48.72 & 48.00 \\
\hline $\mathrm{TiO}_{2}$ & 0.33 & 0.17 & 0.16 & 0.19 & 0.09 & 0.12 & 0.17 & 0.13 \\
\hline $\mathrm{Al}_{2} \mathrm{O}_{3}$ & 1.12 & 0.50 & 0.48 & 0.58 & 0.55 & 0.55 & 0.50 & 0.56 \\
\hline $\mathrm{MgO}$ & 14.71 & 17.94 & 5.87 & 5.98 & 7.18 & 7.16 & 1.68 & 1.34 \\
\hline $\mathrm{F} \in \mathrm{O}$ & 13.93 & 27.48 & 25.87 & 24.35 & 22.82 & 22.55 & 30.59 & 30.15 \\
\hline Mno & 0.55 & 1.00 & 1.24 & 2.69 & 0.75 & 0.83 & 1.03 & 1.03 \\
\hline $\mathrm{CaO}$ & 16.48 & 1.38 & 19.13 & 18.14 & 17.57 & 17.58 & 18.04 & 18.61 \\
\hline $\mathrm{Na}_{2} \mathrm{O}$ & 0.26 & 0.02 & 0.18 & 0.18 & 0.23 & 0.26 & 0.28 & 0.24 \\
\hline $\mathrm{K}_{2} \mathrm{O}$ & & 0.01 & & & & 0.02 & 0.02 & 0.01 \\
\hline Total & 99.79 & 99.45 & 100.46 & 100.25 & 99.96 & 99.37 & 101.03 & 100.07 \\
\hline \multicolumn{9}{|c|}{ Cation ratio based on 6 oxygens } \\
\hline $\mathrm{Si}$ & 1.972 & 1.971 & 1.922 & 1.945 & 2.002 & 1.998 & $1^{\prime} .986$ & 1.980 \\
\hline $\mathrm{Ti}$ & 0.009 & 0.005 & 0.005 & 0.006 & 0.003 & 0.003 & 0.005 & 0.004 \\
\hline A1 & 0.055 & 0.023 & 0.026 & 0.028 & 0.025 & 0.025 & 0.024 & 0.027 \\
\hline $\mathrm{Fe}$ & 0.438 & 0.889 & 0.875 & 0.822 & 0.752 & 0.749 & 1.043 & 1.040 \\
\hline Mn & 0.018 & 0.032 & 0.043 & 0.092 & 0.025 & 0.028 & 0.035 & 0.036 \\
\hline Mg & 0.825 & 1.035 & 0.354 & 0.360 & 0.422 & 0.423 & 0.102 & 0.083 \\
\hline $\mathrm{Ca}$ & 0.664 & 0.057 & 0.829 & 0.784 & 0.742 & 0.748 & 0.789 & 0.823 \\
\hline $\mathrm{Na}$ & 0.019 & 0.002 & 0.014 & 0.019 & 0.018 & 0.020 & 0.022 & 0.020 \\
\hline K & & 0.001 & & & & 0.001 & 0.001 & 0.001 \\
\hline $\mathrm{Ca}$ & 34 & 3 & 39 & 39 & 38 & 38 & 42 & 42 \\
\hline $\mathrm{Mg}$ & 42 & $\$ 1$ & 17 & 18 & 22 & 22 & 3 & 4 \\
\hline $\mathrm{Fe}$ & 24 & 46 & 44 & 43 & 40 & 40 & 55 & 54 \\
\hline
\end{tabular}

1. Augite phenocryst from augite-hypersthene perlite ( $T-11)$, Irihirose, west of Tadami.

2. Hypersthene phenocryst from augite-hypersthene perlite (T-11).

3. Ferroaugite phenocryst from ferroaugite perlite, Suwa pass, Tsugawa.

4. Ditto.

5. Ferroaugite phenocryst from ferroaugite perlite (M-05), Irihirose, west of Tadami.

6. Ditto.

7. Ferrohedenbergite phenocryst from ferrohedenbergite perlite, Kurosawa, Tadami.

8. Ditto.

Total $\mathrm{Fe}$ as $\mathrm{FeO} . \mathrm{Fe}=\mathrm{Fe}^{2+}+\mathrm{Fe}^{3+}+\mathrm{Mn}$

Keweenawan lavas of Minesota. Ca-and Fe- of Australia; by Shimazu and Sawai rich clinopyroxenes in the alkaline volcanic rocks have been also reported by Uchimizu (1966) from Oki island of Japan; by Price and Chappell (1975) from the Dunedin volcano of Otago; by Murray (1954) and Gibb (1973) from the Garbh Eilean sill; by Abbott (1969) from the Nandewar volcano (1975) from the Shidara volcanics. They are mostly sodic ferrohedenbergite. The pyroxenes from Asio and crystallization trends of pyroxenes of the Skaergaard intrusion, British and Icelandic Tertiary acid glasses, and Oki volcanic rocks are shown in Fig. 3 . 


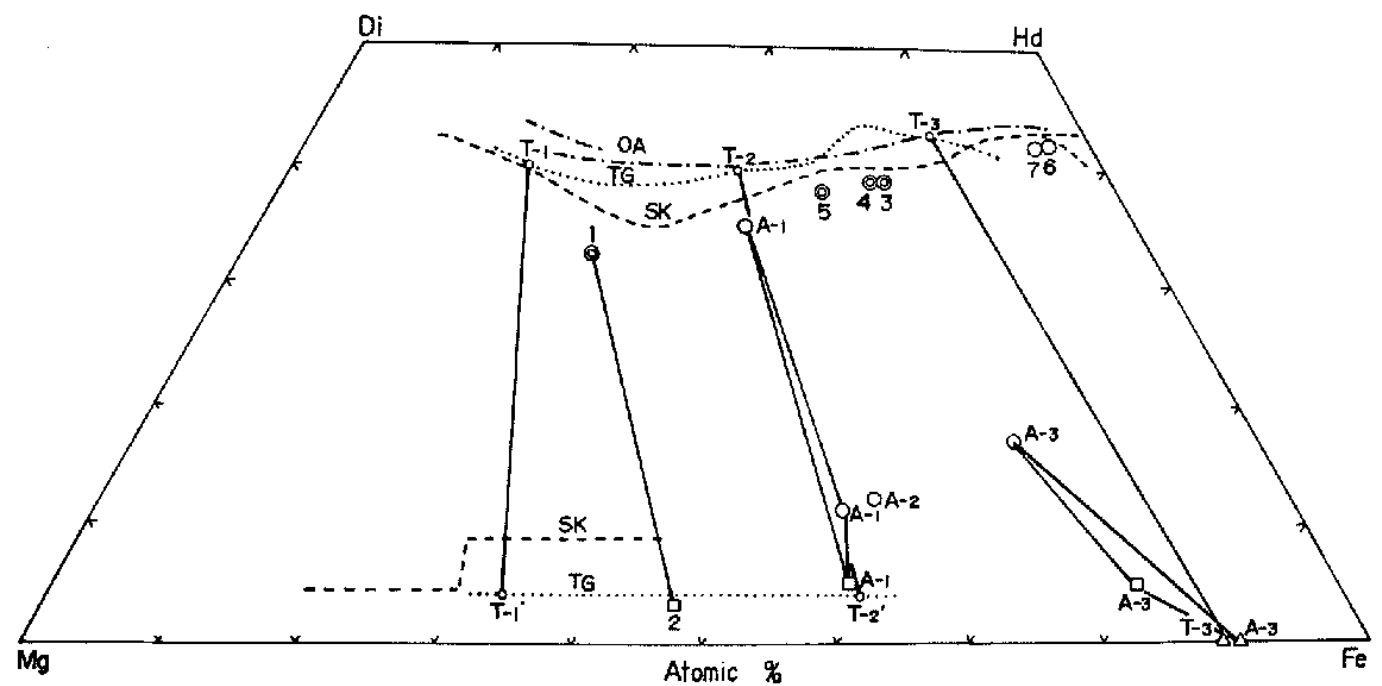

Fig. 3. Chemical compositions of pyroxenes from the Tsugawa and Tadami perlites and Asio volcanics, together with the trends of crystallization of pyroxenes in the Skaergaard intrusion (SK), Tertiary acid glasses (TG) and Oki alkaline rocks (OA). Open circles (6 and 7) represent ferrohedenbergite, double circles ferroaugite $(3,4$ and 5$)$ and augite (1), and open square hypersthene (2). A-1, A-2 and A-3 represent clinopyroxene (open circle), hypersthene (open square) and olivine (triangle) from the Asio volcanics. T-1-T-1', $\mathrm{T}-2-\mathrm{T}-2^{\prime}$ and $\mathrm{T}-3-\mathrm{T}-3^{\prime}$ represent intergrowth of two pyroxenes or pyroxene and olivine in the Tertiary acid glasses.

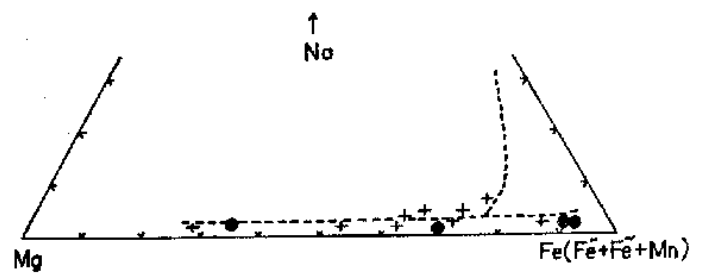

Fig. 4. Chemical compositions of pyroxenes from the Tsugawa and Tadami perlites and Tertiary acid glasses (Carmichael, 1960), together with a trend of pyroxenes of Oki alkaline rocks (Uchimizu, 1969). Solid circles represent the pyroxenes from the perlites, crosses the pyroxenes from Tertiary acid glasses, and a dash line the trend of pyroxenes of Oki alkaline rocks.

\section{Discussion}

The Tsugawa and Tadami perlites have assemblages of augite-hypersthene or ferrohedenbergite - olivine or ferroaugite \pm olivine respectively. Clinopyroxenes from the perlites are plotted nearly on the crystalization trend curve of clinopyroxenes of the tholeiitic Skaergaard intrusion, which is slightly lower than that of the British and Icelandic Tertiary acid glasses (Fig. 3). By the way, as Tertiary acid glasses contain sodic plagioclases or partly alkali feldsaprs, they may be slightly alkalic.

The crystallization trend of clinopyroxenes of the Oki alkaline volcanic rocks is nearly parallel to the Di-Hd join, being more Ca-rich than that of the Skaergaard intrusion. Clinopyroxenes from the Tsugawa and Tadami perlites have lower $\mathrm{TiO}_{2}$, $\mathrm{Al}_{2} \mathrm{O}_{3}$ and $\mathrm{Na}_{2} \mathrm{O}$ contents than the clinopyroxenes from Oki alkaline rocks and the British Tertiary acid glass. The comparison of the crystallization trend and chemical compositions of these pyroxenes suggest 
that pyroxenes of the Tsugawa and Tadami perlites lie on the trend of tholeiitic rocks. However it is difficult to consider these acidic rocks as representing the late stages of fractionation of tholeite magma in the present case, because the acidic rocks have much larger volume than the basaltic rocks and are not accompanied with intermediate rocks in the area. It may has possibility to regard that these rocks were formed from crustal melt as Brown (1963) has suggested for the Skye granophyre. However, it was reproted by Shuto (1969) that these rocks have low strontium ratio (0.7037-0.7046). Origin of the perlites are future problem.

Moreover, from textural relation and An percent of plagioclases it seems that ferroaugite+plagioclase and ferrohedenbergite+olivine+plagioclse, which are phenocrysts in the Tsugawa and Tadami perlites, have simultaneously crystallized, perhaps in deeper part. Accordingly, residual melt (glass of perlite) may have not been equilibrium with the phenocrysts.

Two kinds of Fe-rich pyroxenes are generally found in acid igenous rocks; one is $\mathrm{Ca}-$ and Fe-rich pyroxene (ferroaugiteferrohedenbergite) and another is Ca-poor Fe-rich pyroxene (ferropigeonite-ferrohypersthene). The former is the case of the Tertiary acid glasses by Carmichael (1960), and the late stages of the Skaergaard and Bushveld intrusions, and the Tsugawa and Tadami perlites. The latter is the case of the Hebridean Tertiary acid rocks by Emeleus et al. (1971) and the Asio andesite and dacite by Kuno (1969). The difference between crystallization of $\mathrm{Ca}$ - and $\mathrm{Fe}$-rich pyroxenes and $\mathrm{Ca}$-poor $\mathrm{Fe}$-rich pyroxenes cited above is related to disappearence of Ca-poor Fe-rich pyroxene and appearence of assemblage of ferrohedenbergite-fayalite + (quartz) discussed by Lindsley and Munoz (1969). They have considered that silica activity is main factor controlling the above relation. When silica activity is high, for example, $\quad a_{S i O_{3}}=1$, theoretically Ca-poor pyroxene trend line approachs up to their "forbidden zone" (Lindsley and Munoz, 1969), that is, it means stability of orthopyroxene having high $\mathrm{Fe} / \mathrm{Mg}$ ratio.

Pyroxenes of the Hebridean Tertiary acid rocks and the Asio dacite have high $\mathrm{Fe} / \mathrm{Mg}$ ratio. Although it seems that many of pyroxeres of volcanic rocks crystallized out of equilibirium from variarance of chemical compositions of pyroxenes or mineral paragenesis, if some of them show stable crystallization, these rocks may be more high silica activity than the Tsugawa and Tadami perlites and the British and Icelandic Tertiary acid glasses.

\section{REFERENCES}

Abe, T. and Shimazu, M. (1974), Chemical composition of acid volcanic rocks in the Tsugawa-Aizu province, Northeast Japan. Mining Geology, 24, 355-365 (in Japanese).

Abbot, M.J. (1969), Petrology of the Nandewar volcano, N.S.W., Australia. Contr. Mineral. Petrol., 20, 115-134.

Anwar, Y.M. (1955), A clinopyroxene from the granophyre of Meall Dearg, Skye. Geol. Mag., 92, 367-373.

Atkins, F.B. (1969), Pyroxenes of the Bushveld intrusion, South Africa. $J$. Petrol., 10, 222-249.

Brown, G.M. and Vincent, E.A. (1963), Рyxoxenes from the late stages of fractionation of the Skaergaard intrusion, East Greenland. $J$. Petrol., 4, 175-197.

Brown, G.M. (1963), Melting relations of Tertiary granitic rocks in Skye and Rhum. Mineral. Mag., 33, 533-561.

Carmichael, I.S.E. (1960), The pyroxenes and olivines from some Tertiary acid glasses. $J$. Petrol., 1, 309-336.

(1962), Pantelleritic liquids and their phenocrysts. Mineval. Mag., 33, 86-113. (1967), The iron-titanium oxides of salic volcanic rocks and their associated ferromagnesian silicates. Contr. Mineral. Petrol, 
14. 36-64.

Emeleus, C.H., Dunham, A.C. and Thompson, R. N. (1971), Iron-rich pigeonites from acid rocks in the Tertiary igneous province of Scotland. Am. Mineral., 56, 940-951.

Gibb, F.G.F. (1973), The zoned clinopyroxenes of the Shiant Isles sill, Scotland. J. Petrol., 14, 203-230.

Konda, T. and Green, J.C. (1974), Clinopyroxenes from the Keweenawan lavas of Minnesota. $\mathrm{Am}$. Mineral., 59, 1190-1197.

Kuno, H. (1969), Pigeonite-bearing andesite and associated dacite from Asio, Japan. Am. Jour. Sci., 267-A, 257-268.

Lindsley, D.H. and Munoz, J.L. (1969), Subsolidus relations along the join hedenbergite-ferrosilite. Am. Jour. Sci., 267-A, 295-324.

McDougall, I. (1961), Optical and chemical studies of pyroxenes in a differentiated Tasmanian dolerite. Am. Mineral., 46, 257-268.

Murray, R.J. (1954), The clinopyroxenes of Gargh Eilean sill, Shiant Isles. Geol. Mag., 91, 17-31.

Price, R.C. and Chappel, B.W. (1975), Fractional crystallization and the petrology of Dunedin volcano. Contr. Mineral. Petrol., 53, 157-182.

Sawai, M. and Shimazu, M. (1977), Trachyte dyke in the northern part of Shidara area, Japan (in preparation).

Shuto, K. (1974), On the source materials of acid volcanic rocks in the Cenozoic circum-Pacific belt Considering from their strontium isotope ratios. Ass. Geol. Collab. Japan, Monogr., 18, 91-105.

Uchimizu, M. (1966), Geology and petrology of alkali rocks from Dogo, Oki islands. Jour. Fac. Sci. Univ. Tokyo, Sec. II, 16, 85-159.

\title{
津川，只見地域の中新世直珠岩中の $\mathrm{Ca}, \mathrm{Fe}$ に富んだ愰石
}

\author{
島津光夫・高野 正 樹
}

铁普通輝石や鉄ヘデン輝石のような $\mathrm{Ca}, \mathrm{Fe}$ 亿富んだ輝石の斑晶が，津川，只見地域の中期中新世の地層中に 産する真珠岩熔岩中にみいだれだ。一方，との地域の多くの酸性火山岩は黒雲母か解成石の斑晶を含んでいる。

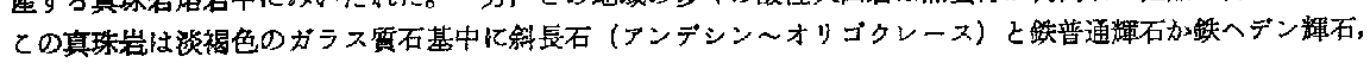
変質したかんらん石，磁鉄鉱の斑晶を含んでいる。

鉄普通輝石や鉄ヘデン辉石は British と Iceland の第三紀酸性ガラスゃ Skaergaard や Bushveld 鿓入岩体の 末期分化物中に生している。また，一部のアルカル岩中にも産する。真珠岩中の $\mathrm{Ca}, \mathrm{Fe}$ に富んだ輝石の化学成 分は， Ca- $\mathrm{Mg}-\mathrm{Fe}$ 梯形ダイアグラム上では、ソレーアイト質岩の輝石の晶出経路の近くにプロットされる。そし て，それらはアルカリ岩中の輝石の組成よりる $\mathrm{TiO}_{2}, \mathrm{Al}_{2} \mathrm{O}_{3}, \mathrm{~K}_{2} \mathrm{O}$ 亿员しい。

Hirotani, . . 広谷, Myoga... 若荷, Suwa pass...骤訪陟

Kamikawa...上川, Irihirose... 入広瀬, Kurosawa... 黑沢 